Politica, Vol. 7, No. 1, Januari-Juni 2020

\title{
POLITIK SEKSUAL TERHADAP ORGANISASI PEREMPUAN PASCA KEMERDEKAAN DI INDONESIA
}

\author{
Muslim Pohan \\ Sekolah Pascasarjana Program Interdisciplinary Islamic Studies, \\ Konsentrasi Islam dan Kajian Gender, UIN Sunan Kalijaga Yogyakarta \\ Muslimpohan@gmail.com
}

\begin{abstract}
Research on Gerwani is documented in a book entitled "The Destruction of the Women's Movement in Indonesia, Sexual Politics in Indonesia Post-Conflict PKI" by Saskia Wieringa. The factor of the massacre and the appearance of Suharto on the stage of power was not only the result of the emergence of sexual metaphors but also the economic turmoil that created a sense of uncertainty in both the army and the communists (the fifth army-the possibility of 21 million peasants and armed laborers escaping AD control). Suharto rose to power by masterminding an unequaled campaign of violence. Not only violence (1965-1966) but also spread slander in the form of allegations of engineering about the occurrence of sexual festivities conducted by members of Gerwani.
\end{abstract}

Keywords: Politics, Sexual: Women's Organization, Post-Independence.

\begin{abstract}
Abstrak
Penelitian ini bertujuan untuk mengetahui bahwa organisasi perempuan pada zaman orde baru bukanlah organisasi yang negatif terhadap masyarakat. Stigma masyarakat terhadap Gerwani pada orde baru dibohongi didokumentasikan dalam buku yang berjudul "Penghancuran Gerakan Perempuan di Indonesia, Politik Seksual Di Indonesia Pascakejatuhan PKI" karya Saskia Wieringa. Faktor terjadinya pembantaian massal dan tampilnya Suharto di panggung kekuasaan tidak hanya akibat pemunculan metafor seksual tapi juga kekacauan ekonomi yang menciptakan rasa tidak menentu di kalangan AD maupun kaum Komunis (angkatan kelima-kemungkinan adanya 21 juta petani dan buruh bersenjata yang terlepas dari kontrol AD). Suharto naik ke tampuk kekuasaan dengan mendalangi kampanye kekerasan yang tidak ada bandingnya. Tidak hanya kekerasan (19651966) tapi juga menyebarkan fitnah berupa tuduhan rekayasa tentang terjadinya pesta seksual yang dilakukan oleh para anggota Gerwani.
\end{abstract}

Kata kunci: Politik, Seksual: Organisasi Perempuan, Pasca Kemerdekaan.

\section{Pendahuluan}

Perkembangan organisasi wanita mulai tumbuh dan berkembang pada revolusi kemerdekaan Indonesia. Perjuangan organisasi kaum wanita terbagi dalam beberapa periode yaitu periode sebelum proklamasi kemerdekaan Indonesia, periode setelah proklamasi kemerdekan (1945-1965), dan periode pasca 1965 
(Orde baru). ${ }^{1}$ Keadaan organisasi wanita dalam setiap periode mengalami perbedaan dari periode sebelumnya. Periode sebelum proklamasi kemerdekaan, organisasi wanita lebih terfokus kepada usaha mengusir penjajahan dan mempertahankan kemerdekaan Indonesia. Setelah periode kemerdekaan (19451965), organisasi wanita memperbaiki nasib kaum wanita dan meningkatkan derajat kaum wanita. Periode Orde Baru, organisasi wanita lebih banyak ditandai oleh berdirinya organisasi istri dan perjuangan organisasi wanita bersifat fungsionalis.

Setelah KOWANI ikut serta menetapkan Soeharto dalam SI MPRS sebagai presiden, KOWANI tidak lagi memperingati Hari Perempuan Internasional yang dirayakan setiap 8 Maret, juga tidak memperingati Hari Anak Internasional 1 Juni. Alasannya Hari Perempuan dan Hari Anak diprakarsai oleh negara-negara komunis. KOWANI itu sebenarnya adalah membangun pemaknaan politik terhadap posisi perempuan sesuai dengan nilai kekoncowingkingan. Tetapi, setelah KOWANI berkonsensus dengan Orde baru, keberagaman pemaknaan posisi politik perempuan diringkus ke sebuah pemaknaan tunggal, yakni menjadi konco wingking rezim yang berkuasa.

Pada 1 Oktober 1965, Achmad Yani dan kawan-kawannya diculik dan dibunuh oleh prajurit Cakrabirawa, yang mengatasnamakan Gerakan 30 September. Mayat ketujuh jenderal tersebut dibuang ke sumur tua di daerah Lubang Buaya. Dengan kejadian tersebut koran ABRI seperti Berita Yudha, membuat head line yang menyatakan keterlibatan Gerakan Wanita Indonesia (Gerwani) dalam peristiwa 1 Oktober 1965. Militer juga menyatakan bahwa Gerwani adalah pelacur yang bejat moral, yang telah menyiksa seksualitas para jenderal sebelum membunuhnya, sambil menari-nari telanjang. Beberapa foto yang dimuat dalam koran tersebut, antara lain bernama Saija, Atika, disebutkan pelacur anggota Gerwani pelaku tindakan tak beradab itu. Dengan demikian GERWANI difitnah dan militer berhasil menanamkan ingatan kolektif masyarakat, bahwa PKI adalah dalang pembunuhan para jenderal dan Gerwani adalah pelacur bejat moral yang menyiksa alat kelamin para jenderal tersebut. Foucault memberi penjelasan bahwa kekuasaan dan pengetahuan adalah dua hal yang tidak bisa dipisahkan. Oleh karena itu, menurut Foucault, bentuk perjuangan tidak hanya melawan eksploitasi saja, namun melawan subjek. ${ }^{2}$

Pada tahun 1974, disahkan UU perkawinan yang mengukuhkan pembagian kerja secara seksual, yakni posisi suami adalah kepala keluarga, sedangkan isteri adalah ibu rumah tangga. Juga lahir PP 10 yang membatasi pegawai pemerintah dan ABRI berpoligini. Akan tetapi, dengan dikukuhkannya pembagian kerja secara seksual dalam UU perkawinan, yang menempatkan posisi suami lebih tinggi

\footnotetext{
${ }^{1}$ Riant Nugroho, Gerakan Perempuan di Indonesia: Gender dan Strategi Pengarus Utamanya di Indonesia. Yogyakarta: Pustaka Pelajar, 2011, hlm. 88.

${ }^{2}$ Saskia E. Wieringa, Penghancuran Gerakan Perempuan: Politik Seksual Di Indonesia Pascakejatuhan PKI (Galangpress, Yogyakarta, 2010), hlm. 410.
} 
dibanding istri, berdampak melemahkan posisi tawar para istri dalam segala keputusan kerumahtanggaan. Kate Millet menjelaskan bahwa seksualitas itu berimplikasi politik seksual.

Gerakan perempuan orde baru tidak terlalu banyak diperbincangan di dunia publik khususnya gerakan perempuan islam di Indonesia. Matinya sejarah gerakan perempuan orde baru di Indonesia dipengaruhi oleh pemerintahan yang otoriter praktis. Gerakan perempuan di Indonesia terlihat setelah pemerintahan Soeharto tumbang dan muncullah masa reformasi, dengan pemeritahan masa reformasilah gerakan perempuan bergerak lebih luas di dunia publik. Sehingga Julia Kristeva mengatakan bahwa berbicara tentang seks tidak hanya jenis kelamin, tetapi bagaimana suami-istri menjadi keluarga yang harmonis dan intelektulal yang bahagia.

\section{Pembahasan}

Masa transisi orde lama menuju orde baru merupakan saat yang sulit bagi pergerakan perempuan di Indonesia. Organisasi perempuan merupakan salah satu elemen yang harus diawasi dan dipasung atas nama kepentingan negara. Indonesia pernah sangat radikal, tetapi terutama dalam politik internasional antiimperialisnya, bukannya politik nasional dalam negeri. Dalam hal ini Angkatan Darat dan partai-partai Islam reaksioner berhasil menggagalkan setiap usaha untuk memperluas pembebasan atau emansipasi golongan-golongan lain selain kaum laki-laki yang berkuasa. Sesudah perebutan kekuasaan tahun 1965, ditegakkanlah suatu pemerintahan birokratik-militer yang kuat, yang dengan efektif menindas dan menghancurkan semua gerakan kiri, termasuk organisasi massa perempuan, GERWANI. Dewasa ini organisasi perempuan diawasi dengan ketat, dan mutlak harus menjalankan politik pemerintah.

Menjelang Pemilu 1955, ${ }^{3}$ Angkatan Darat membentuk Ikatan Pendukung Kemerdekaan Indonesia (IPKI) sebagai partai politik kontestan Pemilu. Namun perolehan suaranya hanya 8 kursi. Kenyataan ini mengecewakan Angkatan Darat yang ingin menguasai gelanggang politik yang pada masa itu telah dikuasai oleh partai-partai politik. Soekarno mengeluarkan konsepsi politik pada 21 Pebruari 1957, dengan maksud untuk pengobat kecewa para kontestan yang kalah. Konsepsi politik itu berisi, pertama, pembentukan kabinet kaki empat (Masyumi, PNI, NU dan PKI). Kedua, pembentukan Dewan Nasional (Denas) yang dipimpinannya sendiri, beranggotakan empat kepala staf Angkatan, wakil golongan fungsional dan daerah. Melalui Denas inilah golongan fungsional yang kemudian mengubah nama menjadi golongan karya (bukan Golkar) mengembangkan posisinya dalam lembaga politik, untuk memuluskan peranan politik dwifungsi militer.

${ }^{3}$ Lihat Ulf Sundhaussen, Politk Militer Indonesia 1945-1967 Menuju Dwi Fungsi ABRI, LP3ES, Jakarta, cetakan pertama 1986. Lihat juga, AH Nasution Memenuhi Panggilan Tugas jlid 3: Masa Pancaroba Pertama, PT Gunung Agung, Jakarta, 1983. 
Melalui Dekrit 5 Juli 1957, Sukarno membubarkan Konstituate untuk kembali ke UUD 45. Beberapa bulan setelahnya, Sukarno membubarkan Parlemen hasil Pemilu 1955, dan kemudian setelah mendengar saran dari pimpinan Nasakom-Mil (Ali Sastroamidjojo, Idham Chlaid, DN Aidit dan Mayjen Wiluyo Puspoyudo) dalam pertemuan di Tampaksiring Bali, Sukarno mengumumkan susunan DPR Gotong Royong yang separuh terdiri golongan politik (partai-partai) dan separuh golongan karya. Tak lama kemudian susunan MPR-S yang juga berporos Nasakom-Mil diumumkan. Hampir sepertiga anggota Kabinet dan DPRGR berasal dari militer yang memberi status dirinya sebagai golongan karya angkatan bersenjata.

Sejalan keberhasilan dan legitimasi UUD 45 masuk ke arena eksekutif dan legislatif ini, langkah militer selanjutnya adalah melebur ketiga satuan angkatan perang dan kepolisian menjadi Angkatan Bersenjata Republik Indonesia (ABRI). Masing-masing Kepala Staf Angkatan tersebut diberi kedudukan Sukarno sebagai menteri negara. Tetapi, sejak berlakunya SOB (staat van oorlog en van Beleg) pada Maret 1957 Indonesia berada dalam keadaan darurat militer, dan sebenarnya militer sudah menguasai pemerintahan dan lembaga-lembaganya.

Peleburan satuan angkatan tersebut berpengaruh pada nasib organisasi isteri angkatan perang dan kepolisian. Semula Persit (organisasi isteri AD), Pia Ardhya Garini (organisasi isteri AU), Yalasenastri (organisasi isteri AL), Bhayangkari (organisasi isteri Polisi), berdiri otonom dan tidak menjadi bagian dari struktur angkatan perang dan kepolisian. Sebagai contoh adalah Persit, ${ }^{4}$ meskipun anggotanya adalah isteri $\mathrm{AD}$, organisasi ini terpisah dari struktur kedinasan AD. Para aktivisnya mencari dana di luar kedinasan suaminya, dan para pengurus dipilih berdasarkan kecakapannya bukan karena jabatan suaminya. Persit mempunyai agenda untuk memperjuangkan kepentingan perempuan, khususnya isteri Angkatan Darat. Agenda perjuangan mereka yang penting dicatat adalah memperjuangkan kenaikan gaji janda militer, baik yang suaminya gugur di medan perang maupun karena mati alamiah. Agenda lainnya adalah memperjuangkan hak suara perempuan ke Departemen Agama dalam penyusunan UU Perkawinan. Untuk menjalankan roda organisasi dan agenda perjuangannya tersebut, Persit membangun bidang usaha secara mandiri.

Politik perempuan Persit ini tidak disukai Jenderal Achmad Yani, karena dianggap tidak layak, karena itu organisasi ini diintervensi untuk mengadakan Kongres. Achmad Yani berpidato di depan Kongres tersebut bahwa Persit hanya boleh memiliki satu sikap politik, yakni doktrin militer, dan tidak boleh berpolitik di luar doktrin itu. Achmad Yani juga minta agar Persit tidak boleh berdiri otonom dan terpisah dari kesatuan AD. Permintaan Achmad Yani ini ditolak oleh Dewan Pengurus Pusat Persit yang dipimpin Ny. Sunarti (isteri Nasution)

${ }^{4}$ Dalam bukunya AH Nasution, Memenuhi Panggilan Tugas, Jilid 5, CV Haji Masagung, Jakarta, 1989 
Achmad Yani menarik paksa perwakilan Persit di KOWANI. Tetapi tindakannya itu tetap tidak dihiraukan Persit, hingga Achmad Yani membekukan Dewan Pengurus Pusat Persit. Kemudian, Achmad Yani membentuk caretaker untuk mengadakan kembali Kongres Persit. Dalam Kongres tersebut, struktur organisasi Persit dirombak dan disatukan ke dalam satuan Angkatan Darat. Nama Persit diubah menjadi Kartika Candra Kirana. Langkah Achmad Yani ini juga dilakukan terhadap Pia Ardhya Garini, Yalasenastri dan Bhayangkari, yang keotonomian organisasi itu dilebur ke dalam satuan dinas suami masing-masing. Keempat organisasi isteri itu kemudian disatukan dalam payung Badan Kerja Sama (BKS) Dharma Pertiwi pada 1964, dan sejak 1966 bernaung di bawah pembinaan HANKAM ABRI. ${ }^{5}$ Kemudian pada 1972, sebutan BKS dihapus dari Dharma Pertiwi dan tinggalah Dharma Pertiwi saja sebagai organisasi isteri ABRI.

Setelah otonomi politiknya dihancurkan, politik BKS Dharma Pertiwi tunduk tanpa reserve di garis belakang ABRI. Mereka mendapat doktrin militer yang menekankan pada ketundukan dan kepatuhan komando. Dharma Pertiwi tercatat sebagai salah satu anggota Sekretariat Bersama Golongan Karya (Sekber Golkar) yang dimotori Angkatan Darat untuk membendung kegiatan PKI dan simpatisannya. ${ }^{6}$ Organisasi perempuan yang masuk ke Sekber Golkar meliputi unsur ABRI, organisasi-oraginsasi perempuan yang berasas agama, organisasi perempuan yang punya ikatan dengan Partai Sosialis Indonesia (PSI) dan organisasi perempuan pegawai Departemen-departeman dan Lembaga non Departemen (IKWANDEP, Ikatan Wanita antar Departemen yang didirikan pada 1964). ${ }^{7}$

\section{Gerwani dan Lubang Buaya}

Keterlibatan perempuan dalam pembunuhan di Lubang Buaya ialah karena dengan kemurtadan dan komunis yang gila Gerwani menjadi tangan utama penyiksaan dan pembunuhan para jenderal. Mereka konon dengan bertelanjang dada serta memotong penis para jenderal (bahkan dikatakan mengulum potongan penis itu). Memang benar sejumlah perempuan dari pemuda rakyat dan Gerwani berada di tempat latihan Lubang Buaya. Tetapi Gerwani tidak terlibat dalam kudeta, meskipun pada waktu itu gerwani bersekutu dengan PKI. Terkait dengan anggota Gerwani yang berada di Lubang Buaya tersebut, pada 30 September Suharti datang ke kantor pusat Gerwani dan memberitahukan kepada mereka yang hadir bahwa diperlukan sejumlah tenaga perempuan untuk latihan Dwikora di

\footnotetext{
${ }^{5}$ Lihat Sejarah 50 tahun KOWANI hal. 172

${ }^{6}$ Dalam bukunya Sukanti Suryocondro berjudul Potret Pergerakan Wanita Indonesia, Yayasan Ilmu-ilmu Sosial, Jakarta, 1984, disebutkan bahwa dalam usaha untuk membendung kegiatan Partai Komunis Indonesia (PKI), Angkatan Darat memprakaarsai berdirinya Sekretariat Bersama Golongan Karya (Sekber Golkar) dan mengajak organisasi perempuan masuk ke dalamnya. Dharma Pertiwi sebagai bagian dari Angkatan Darat otomatis masuk ke Sekber Golkar ${ }^{7}$ Sejarah 50 tahun KOWANI.
} 
Lubang Buaya. Ternyata Gerwani diminta menyiapkan konsumsi untuk para pemberontak serta membuka dapur umum.

Sulami menjemput empat orang anggota Gerwani dan mengirimkannya ke Lubang Buaya. Kemudian Sulami kembali ke kantor pusat. Kejadian berikutnya yang diketahui kantor pusat Gerwani adalah informasi di Radio pada pagi berikutnya bahwa telah terjadi suatu kudeta dan pada pai pagi itu juga anggota Gerwani dan sejumlah gadis yang berkumpul di Lubang Buaya kebingungan pulang ke kantor pusat Gerwani dengan membawa informasi pembunuhan yang membingungkan. Bukan hanya anggota Gerwani yang berada di Lubang Buaya, masih ada para perempuan muda dan gadis yang berkumpul di lokasi tersebut. Mereka ialah para sukarelawati dan istri prajurit Cakrabirawa, ada juga yang bukan anggota Gerwani. Para sukarelawati dan gadis muda tersebut yang berumur 13 sampai 16 tahun. $^{8}$

\section{Gerwani Terperangkap dan difitnah}

Pihak AD bersusah payah sebelum berhasil menyusun kisah-kisah yang hendak disiarkan. Saksi-saksi dikutip dan foto-foto dicetak di koran-koran. Televisi dan radio menyiarkan tentang kisah horor yang konon terjadi di Lubang Buaya. Terdapat tiga orang perempuan dewasa di Lubang Buaya, diantaranya Saina, Emy, dan Atikah. Pihak militer mulai melakukan pengejaran terhadap mereka. Ada dua orang pelacur bernama Saina dan Emmy. Kedua orang pelacur itu disiksa habis-habisan. Emy melarikan diri dan Saina tertangkap.

Anggota Gerwani tidak melakukan perbuatan pelecehan dan kekerasan seksual terhadap jenderal, tetapi militer AD yang menggunakan segala macam cara dan alat untuk melakukan penyiksaan seksual terhadap para tahanan politik mereka. Mantan Gerwani yang ditahan di penjara bersama para pemudi sukrelawati Lubang Buaya menyampaikan pengalamannya sebagai berikut:

Secara luas dilaporkan ke media massa bahwa mereka mencungkil mata para jenderal, memotong penis mereka setelah melakukan hubungan seks. Informasi semacam ini disebarkan melalui koran. Salah satu berita menyatakan para anggota Gerwani membuka pakaian dan telanjang bulat menari-nari yang disebutnya tarian harum bunga. Saya bertanya kepada anak-anak muda itu akan kebenarannya. Dalam kenyataannya mereka ditahan di Lubang Buaya, mereka disiksa berat, beberapa diperkosa dan kemudian mengalami gangguan mental.

Keterlibatan perempuan dalam pembunuhan para Jenderal dipenjara selama 14 tahun tanpa pernah dijatuhi hukuman, pada 10 Oktober di Radio dan koran-koran disiarkan tentang penyiksaan seksual terhadap Gerwani dan November 1965 mantan sukarelawati berumur 16 tahun terperangkap di Lubang Buaya. Dipaksa

${ }^{8}$ Saskia E. Wieringa, Penghancuran Gerakan Perempuan: Politik Seksual di Indonesia Pascakejatuhan PKI, hlm. 424-428. 
telanjang bulat dan menari-nari dan pihak AD mengambil gambarnya. Pada 1 Oktober (dinihari) 1965, Achmad Yani dan kawan-kawannya diculik dan dibunuh oleh prajurit Cakrabirawa, yang mengatasnamakan Gerakan 30 September. Mayat ketujuh jenderal tersebut dibuang ke sebuah sumur tua di daerah Lubang Buaya. Pada hari itu juga Panglima KOSTRAD, Mayjen Soeharto mengumumkan di Radio bahwa tentara telah berhasil membekuk Gerakan 30 September yang dipimpin PKI untuk mengambil alih kekuasaan yang sah. Beberapa hari kemudian, terjadi perburuan dan penangkapan anggota PKI dan ormas-ormasnya secara besar-besaran di seluruh Indonesia. ${ }^{9}$

Koran-koran, terutama koran ABRI seperti Berita Yudha, membuat head line yang menyatakan keterlibatan Gerakan Wanita Indonesia (Gerwani) dalam peristiwa 1 Oktober 1965. Militer menyatakan bahwa Gerwani adalah pelacur yang bejat moral, yang telah menyiksa seksualitas para jenderal sebelum membunuhnya, sambil menari-nari telanjang. Beberapa foto yang dimuat dalam koran tersebut, antara lain bernama Saija, Atika, disebutkan pelacur anggota Gerwani pelaku tindakan tak beradab itu. ${ }^{10}$ Dengan demikian militer berhasil menanamkan ingatan kolektif masyarakat, bahwa PKI adalah dalang pembunuhan para jenderal dan Gerwani adalah pelacur bejat moral yang menyiksa alat kelamin para jenderal tersebut. Pandangan masyarakat terhadap perempuan negatif dan Gerwani difitnah dalang kejadian tersebut. Sejak saat itu Gerwani dijadikan preseden buruk bagi organisasi perempuan yang bekerja di garis massa. Fitnah terhadap keterlibatan Gerwani dalam kudeta pertama 1 Oktober 1965 semakin dipercaya secara luas. Dan ditengah gelombang teror yang sebagian besar dikarenakan berbagai kebohongan ini, beratus-ratus ribu orang tak bersalah dibantai dan dipenjarakan. ${ }^{11}$

\section{Pemantaban Kekuasaan Orde Baru 1970 - 1984}

UU Perkawinan yang mengukuhkan pembagian kerja secara seksual, yakni posisi suami adalah kepala keluarga, sedangkan isteri adalah ibu rumah tangga, disahkan. Juga lahir PP 10 yang membatasi pegawai pemerintah dan ABRI berpoligini. Akan tetapi, dengan dikukuhkannya pembagian kerja secara seksual dalam UU Perkawinan, yang menempatkan posisi suami lebih tinggi dibanding isteri, berdampak melemahkan posisi tawar para isteri dalam segala keputusan kerumahtanggaan. Pemantaban kekuasaan militer Orde Baru ini, Panca Dharma Wanita diresmikan sebagai sistem normatif anggota Dharma Pertiwi, Dharma Wanita dan PKK Teks resmi itu berisikan: Wanita Indonsia berfungsi melaksanakan tugas (1) sebagai pendamping suami, (2) sebagai ibu yang melahirkan dan mengasuh anak, (3) sebagai pengatur ekonomi rumah tangga, (4)

\footnotetext{
${ }^{9}$ Ibid, hlm. 414.

${ }^{10}$ Ibid, hlm. 415.

${ }^{11}$ Saskia E. Wieringa, Penghancuran Gerakan Perempuan: Politik Seksual di Indonesia Pascakejatuhan PKI, hlm. 432-436.
} 
sebagai pencari nafkah tambahan, (5) sebagai anggota organisasi sosial kemasyarakatan. Masa ini adalah masa keberhasilan ORBA, misalnya program KB dan swasembada pangan, Ketika BKKBN mengejar target akseptor, anggota PKK dikumpulkan, lalu didaftar yang belum ber-KB dan selanjutnya diberi alat kontrsepsi sesuai yang telah disediakan Petugas Lapangan KB.

\section{Kesimpulan}

Dari sudut politik, organisasi-organisasi perempuan, seperti halnya semua organisasi massa, telah kehilangan kekuatan atau pengaruhnya yang pernah dimiliki selama periode perjuangan kemerdekaan nasional atau selama tahuntahun pertama republik merdeka di bawah pemerintahan Presiden Sukarno. Hilangnya pengaruh ini terjadi ketika perjuangan kemerdekaan nasional akhirnya selesai, dan partai-partai besar di Indonesia berhasil memperoleh kekuasaan politik di negeri ini. Melalui organisasi-organisasi istri dan PKK, kaum birokrat militer yang berkuasa berusaha menguasai kaum perempuan dan laki-laki lapisan bawah dalam hirarki pemerintahan di Indonesia. Anggota-anggota lapisan bawah dan berusia muda dalam organisasi-organisasi ini sering merasa jengkel karena harus ikut serta dalam kegiatan karena mereka hampir tidak punya pengaruh apapun pada apa yang terjadi dalam organisasi. Namun demikian, mereka dibebani tekanan sosial yang berat, juga melalui suami mereka, untuk hadir dalam rapat-rapat dan ambil bagian dalam kegiatan-kegiatan.

Dengan demikian melalui kombinasi pengukuhan subordinasi kaum perempuan secara terorganisasi dan rezim kapitalis militer yang represif, kaum perempuan di semua lapisan masyarakat Indonesia itu dikontrol. Bentuk struktur hirarkis organisasi-organisasi perempuan di Indonesia dewasa ini memudahkan pengekangan kaum perempuan miskin. Karena itu "kuntilanak wangi," sebutan populer untuk organisasi-organisasi istri itu, menjadi alat penindas terhadap sesama saudari yang miskin, dan bukannya membantu mereka, yang sekaligus memperkokoh subordinasi para anggota mereka sendiri.

Gerakan perempuan orde baru tidak terlalu banyak diperbincangan di dunia publik khususnya gerakan perempuan islam di Indonesia. Matinya sejarah gerakan perempuan orde baru di Indonesia dipengaruhi oleh pemerintahan yang otoriter praktis, yaitu Soeharto. Gerakan perempuan di Indonesia terlihat setelah pemerintahan Soeharto tumbang dan muncullah masa reformasi, dengan pemeritahan masa reformasilah gerakan perempuan beergerak lebih luas di dunia publik. 


\section{Daftar Pustaka}

Nugroho, Riant. Gerakan Perempuan di Indonesia: Gender dan Strategi Pengarus Utamanya di Indonesia. Yogyakarta: Pustaka Pelajar, 2011

Wieringa, Saskia E. Penghancuran Gerakan Perempuan: Politik Seksual Di Indonesia Pascakejatuhan PKI (Galangpress, Yogyakarta, 2010)

Sundhaussen, Ulf. Politk Militer Indonesia 1945-1967 Menuju Dwi Fungsi ABRI, LP3ES, Jakarta, cetakan pertama 1986.

Nasution, AH. Memenuhi Panggilan Tugas jlid 3: Masa Pancaroba Pertama, PT Gunung Agung, Jakarta, 1983

Memenuhi Panggilan Tugas, Jilid 5, CV Haji Masagung, Jakarta, 1989. 